\title{
Representasi Karakter Ayah pada Film NKCTHI: Nanti Kita Cerita tentang Hari Ini
}

Tigy Ambar Silvanari

\author{
| Program Studi Ilmu Komunikasi, Pembangunan Jaya University, Banten, Indonesia, Bisa \\ dihubungi melalui email: tigyambar@gmail.com
}

\begin{abstract}
ABSTRAK
The background of this research is motivated by an interest in the patriarchal cultural practices that apply to Indonesian society. Where one of them is related to the dominance of men as fathers in the family sphere. A number of roles in the family are constructed in the position of the father. Film is one of the media that can portray father as the main character. The depiction of the father character in Indonesian films in the 90s has shifted from the 2000s to the present. One of the family-themed films that make the main character of the father in the current era is the NKCTHI: Nanti Kita Cerita Tanpa Hari film. This film is interesting to study, because the character of the father is shown by taking pictures from various points of view. So it would be interesting if a study was conducted on the depiction of the father's character in the NKCTHI: Nanti Kita Cerita Tentang Hari Ini film. This study uses a qualitative method with Peirce's semiotic analysis to get a picture of the representation of the father's character through the signs, objects, and interpreters in the scenes in the NKCTHI: Nanti Kita Cerita Tanpa Hari ini film. The results of this study indicate that the character of the father in this film is still represented as a dominant figure through his role as a protector so that it can be associated with the practice of patriarchal culture that is still valid in Indonesia, especially in the family sphere.
\end{abstract}

Keywords : Film, Peirce's Semiotic Analysis, Representation, Father's Role, Patriarchy Culture.

\section{Pendahuluan}

Di Indonesia, hingga saat ini budaya patriarki masih mengakar. Patriarki yang berasal dari kata patriarkat merupakan struktur yang menempatkan laki-laki sebagai penguasa tunggal, sentral, dan segalanya. Sejak masa meramu dan berburu, praktik patriarki sudah terjadi. Beberapa daerah di Indonesia pun masih memegang kuat aturan adat mengenai posisi laki-laki yang lebih tinggi (Revitasari, 2019). Adanya sistem patriarki yang dominan dalam sebuah kebudayaan dapat berpengaruh pada aspek-aspek dalam kegiatan masyarakat dan ketidakadilan gender. Perempuan memiliki peran terbatas yang membuatnya berada pada posisi terdominasi, sedangkan lakilaki dianggap menjadi sosok yang dapat memberikan kontrol utama(Rokhmansyah, 2013).

Sistem patriarki yang turun temurun menempatkan laki-laki memiliki posisi yang tinggi dalam sebuah struktur sosial. Hal ini menyebabkan adanya bentuk ketidakadilan bagi perempuan. Pada dunia profesional pun perempuan sering kali berada pada posisi manusia tingkat dua (Rizqullah, 2019). Tidak sedikit orang-orang yang berada di daerah tertentu menganggap perempuan sebagai sosok yang tidak bisa berpendapat dan laki-laki sebagai 
seorang pemimpin. Perempuan dianggap sebagai sosok yang hanya boleh berkarya dalam zona nyaman, sehingga sulit untuk tumbuh dan menuruti keinginan dalam menciptakan sebuah karya prestasi baru. Dalam bidang politik pun, perempuan juga tidak mendapatkan hak dan ruang yang sama dengan laki-laki. Perempuan juga masih dianggap sebagai seseorang yang tidak kompeten dibandingkan laki-laki yang harus lebih berani dan kuat(Rahman, 2020).

Ayah sebagai sosok laki-laki dalam keluarga juga dianggap sebagai seseorang yang dapat membuat semua keputusan dalam keluarga hingga menguasai seluruh anggota keluarganya. Sejak zaman nenek moyang budaya patriarki ini juga sudah turun temurun hadir di Indonesia (Tan, 2014). Pasal 25 RUU Ketahanan Keluarga menyatakan bahwa suami yang menjadi kepala keluarga memiliki tanggung jawab untuk memberi keperluan hidup, mensejahterakan keluarga, dan memiliki tanggung jawab dalam legalitas kependudukan dari keluarganya. Sedangkan istri berperan untuk mengatur rumah tangga dengan sebaik-baiknya, memenuhi hak suami serta anak yang sesuai dengan norma agama, hingga menjaga keutuhan dalam keluarga. Pasal tersebut juga dianggap dapat berpotensi memberi batasan ruang gerak hingga mendomestikasi peranan seorang perempuan(Suyanto, 2020).

Dalam keluarga, ayah memberikan kontrol yang lebih besar dibandingkan istri yang hanya mendapat pengaruh ataupun suara yang lemah dan kecil. Hal ini mendorong adanya ketidaksetaraan gender yang berpengaruh pada aspek-aspek dan bidang tertentu. (Sukarno, 2019). Seharusnya, demi menjaga keseimbangan yang ada dalam sebuah keluarga ada pembagian peran yang seimbang sehingga masing-masing anggota keluarga dapat menjalankan peran maupun tugas masing masing. Tugas dari seorang ayah dan ibu dalam keluarga juga harus dilakukan dengan seimbang dan hasil dari kesepakatan bersama dengan tujuan menciptakan keharmonisan dan keberhasilan dalam keluarga (Lestari, 2012, pp. 66-68).

Ayah memang dominan memiliki sisi maskulin dalam keluarga, namun peranan ibu dan ayah seharusnya dapat diibaratkan sebagai suatu keseimbangan agar dapat memberi kesejahteraan dalam keluarganya terutama dalam proses perkembangan seorang anak (Agmassini, 2019). Ayah menjadi panutan dalam memimpin keluarga, namun selain menjadi penegak disiplin ayah juga diharapkan dapat menjadi sosok yang bisa menjadi teman untuk menerima curahan hati dengan interaksi dengan kehangatan dan kelembutan (Dewi, 2017). Salah satu media yang dapat memberikan gambaran dalam sebuah kondisi tertentu yang ada dalam masyakarat adalah film. Dalam komunikasi, film merupakan bagian yang penting dalam sistem yang dapat digunakan bagi para individu maupun kelompok untuk mengirim dan menerima sebuah pesan. Pada hakikatnya, sebuah film merupakan bentuk dari dokumen sosial maupun budaya yang dapat membantu dalam mengkomunikasikan sebuah zaman saat film tersebut dibuat, bahkan sekalipun tidak pada saat zaman tersebut ketika film itu dibuat(Ibrahim I.S., 2011)

Film merupakan sebuah karya cipta seni dan budaya yang termasuk kedalam media komunikasi massa. Film terdiri dari rangkaian 
gambar yang bergerak dan membentuk suatu cerita. Terdapat beberapa keistimewaan dari media film seperti dapat menghadirkan pengaruh secara emosi yang kuat, memberikan motivasi dalam membuat suatu perubahan, mengilustrasikan sebuah kontras visual secara langsung, hingga berkomunikasi dengan penonton tanpa batas yang menjangkau (Javandalasta, 2011). Saat ini, film masih menjadi media komunikasi massa yang populer. Hal ini dikarenakan dalam sebuah film terdapat alur cerita yang menarik dan disertai oleh efek suara yang baik sehingga menjadi alasan mengapa khalayak dapat menikmati sebuah film tanpa harus mengimajinasikannya seperti saat membaca buku(Romli, 2016).

Pada era 90-an karakter laki-laki digambarkan dalam film sebagai sosok yang dapat memberi nafkah, pelindung, dan sebagai kepala rumah tangga. Salah satunya adalah pada film 'Catatan Si Boy.' Pada film tersebut sosok Boy ditampilkan sebagai laki-laki maskulin yang menyukai olahraga dan populer. Selain itu pada film lain seperti 'Pengkhianatan G30S/PKI' dan 'Di Balik Kelambu, ' laki-laki direpresentasikan sebagai sosok maskulin yang memiliki peran dalam melindungi keluarga dan memiliki kuasa dalam keluarga sebagai sosok suami. Namun pada era tahun 2000-an terjadi pergeseran dalam penyajian sosok laki-laki, ditunjukkan dengan adanya perubahan dan variasi dalam maskulinitas baru yang digambarkan sebagai laki-laki yang lebih ekspresif, lembut, terlibat dalam pekerjaan rumah tangga, serta turut serta dalam pengasuhan terhadap anak. Seperti pada film 9 Summers 10 Autumns yang memberikan tampilan peran laki- laki sebagai karakter yang menentang budaya kekerasan dalam mendidik anak. Serta film Lovely Man yang menggambarkan karakter ayah sebagai seorang waria(Eliyanah, 2018).

Beberapa tahun belakangan ini, industri film Indonesia juga banyak mengeluarkan film dengan tema keluarga yang menonjolkan bagaimana peran laki laki sebagai seorang ayah. Film dengan tema keluarga ini memiliki latar belakang cerita yang biasanya mengusung suatu konflik yang cukup rumit. Selain dapat membawa emosi tawa dan air mata, film dengan tema keluarga juga memiliki manfaat dalam memberikan pesan-pesan dalam kehidupan sosial sehari-hari, selain itu film keluarga biasanya juga mengisahkan tentang kisah yang dekat dengan kehidupan sehari-hari. Film genre keluarga juga bisa memberikan inspirasi kepada penonton, dan dapat menjadi motivasi dalam hal menuntaskan permasalahan(Hidayat L. , 2019).

Salah satu film keluarga yang mengangkat karakter dari seorang ayah baru-baru ini adalah film NKCTHI: Nanti Kita Cerita Tentang Hari. Film yang diangkat dari buku karya Marcella FP ini digarap menjadi sebuah film yang sukses di pasaran dan disutradarai oleh Angga Dwimas Sasongko. Menceritakan sebuah keluarga yang telihat bahagia namun di balik kebahagiaan tersebut, ketiga kakak beradik memiliki cerita pilu masing-masing yang membentuk karakter mereka saat dewasa. Perubahan-perubahan yang tejadi dalam kehidupan mereka membuat orang tua dari keluarga tersebut mulai memberikan tekanan kepada anak-anaknya. Film ini menjadi film Indonesia pertama pada tahun 2020 yang mendapat dua juta lebih penonton. Selain itu 
banyak yang memuji bahwa film ini benar-benar memberikan pesan bagi seluruh keluarga Indonesia(Noor, 2020).

Karakter ayah pada film ini diperlihatkan sebagai ayah yang tidak ingin anaknya merasa kecewa, gagal, dan bersedih sehinggga hal tersebut membuat sang ayah menjadi seseorang yang terlalu protektif. Sikap ingin melindungi dari sang ayah pada akhirnya membuat anaknya terutama Awan, tidak tahu bagaimana rasanya memilih apa yang ia inginkan, karena semua keputusan mengenai hidupnya diwakilkan oleh sang ayah (Skata, 2020). Dibandingkan dengan film Indonesia lain yang mengangkat karakter seorang ayah seperti pada film Sabtu Bersama Bapak, Tampan Tailor, Check Toko Sebelah, Keluarga Cemara, film NKCTHI: Nanti Kita Cerita Tentang Hari ini memperlihatkan bagaimana sosok ayah yang menjadi kepala keluarga dominan dalam menuntun anak mereka terutama anak bungsunya dari kecil hingga dewasa untuk menjalankan kehidupan sesuai dengan yang diharapkannya(Luviana, 2020).

Alasan peneliti memilih film NKCTHI: Nanti Kita Cerita Tentang Hari ini jika dikaitkan dengan penjelasan yang telah dijabarkan sebelumnya adalah karena film ini merupakan satu dari sedikit film Indonesia yang memposisikan ayah berbeda dengan film Indonesia pada umumnya. Jika dilihat dari sosok dominan dalam budaya patriarki, karakter ayah juga ditampilkan sebagai sosok yang turut serta dalam pekerjaan domestik dalam membantu istri. Hal tersebut dilihat dari salah satu adegan saat sang ayah membantu sang istri untuk mempersiapkan makan malam dan memasak bagi anggota keluarganya. Selain itu alasan lain yang memperkuat mengapa peneliti memilih film ini, dikarenakan NKCTHI: Nanti Kita Cerita Tentang Hari Ini juga merupakan film Indonesia pertama yang baru hadir pada awal tahun 2020 dan mendapat sebanyak dua juta lebih penonton. Sedangkan pada film lain yang sama-sama mengangkat karakter ayah hanya mencapai tujuh ratus ribu penonton(Diananto, 2020).

Pada penelitian terdahulu dengan judul 'Representasi Kasih Sayang Ayah Kepada Anak Dalam Film Animasi "Shelter" (Analisis Semiotika Tentang Representasi Kasih Sayang Ayah Kepada Anak Dalam Film Animasi Shelter' karya Ahmad Fattah Kurniawan pada tahun 2019 dengan metode penelitian kualitatif semiotika. Dengan tujuan untuk melihat bagaimana bentuk dari representasi kasih sayang seorang ayah kepada anak mendapatkan hasil berupa peran ayah pada film Shelter menunjukan representasi kasih sayang. Penelitian serupa lainnya karya Putu Ayu Widiyasa (2017) dengan judul 'Representasi Maskulinitas Pada Sosok Ayah di Majalah Keluarga Ayahbunda' dengan metode kualitatif semiotika mendapat hasil yang menunjukan bahwa dalam majalah tersebut sosok ayah digambarkan sebagai seseorang yang peduli terhadap keluarga dan perkembangan anaknya. Selain itu terdapat penelitian karya Fany Gabriella Adipoetra yang berjudul 'Representasi Patriarki dalam Film Batas' pada tahun 2016 dengan pendekatan kualitatif metode semiotika. Hasil pembahasan dari penelitian ini menemukan bahwa dalam film Batas kaum laki-laki mendapatkan sebuah harapan dan perempuan tidak memiliki kesempatan yang sama. 
Dapat dilihat perbedaan dari ketiga penelitian yang telah dilakukan sebelumnya adalah penelitian ini memiliki fokus penelitian terhadap karakter ayah dalam keluarga yang terkait dengan budaya patriarki. Sedangkan pada penelitian sebelumnya, karakter ayah hanya direpresentasikan sebagai sosok yang menggambarkan karakter yang maskulin. Selain itu representasi patriarki yang diperlihatkan juga mencakup pada peran laki-laki terhadap perempuan tidak fokus terhadap peran seorang ayah dalam keluarga seperti yang difokuskan pada penelitian ini.

Namun dari hasil penelitian terdahulu yang telah dijelaskan sebelumnya, sosok ayah pada majalah dan juga film tersebut juga direpresentasikan sebagai sosok yang dapat memberikan kasih sayang kepada keluarganya. Sehingga hal ini juga dapat dikaitkan sebagai hasil yang dapat memperkuat penelitian ini. Peran ayah merupakan bentuk dari kasih sayang dan tanggung jawabnya sebagai seorang kepala keluarga.

Dapat dilihat juga bahwa sebuah media baik itu film maupun majalah dapat merepresentasikan kondisi atau konsep tertentu yang terkait dengan medianya. Selain itu film juga menjadi media yang dapat memberikan edukasi kepada masyarakat. Melihat dominannya karakter ayah pada film Nanti Kita Cerita Tentang Hari Ini memperlihatkan berbagai sudut pandang seperti salah satunya adalah gambaran budaya patriarki, maka peneliti ingin melihat bagaimana representasi karakter ayah yang ada pada film NKCTHI: Nanti Kita Cerita Tentang Hari Ini. Penelitian ini akan menggunakan penelitian kualitatif dengan analisis semiotika Charles Sanders Pierce sehingga pada hasil akhir penelitian ini akan mengambarkan bagaimana karakter dari peran ayah dalam film tersebut.

Berdasarkan paparan latar belakang di atas maka rumusan masalah dalam penelitian ini adalah "Bagaimana karakter ayah direpresentasikan dalam film NKCTHI: Nanti Kita Cerita Tentang Hari Ini?"

\section{KAJIAN PUSTAKA}

\section{Representasi}

Representasi merupakan sebuah penggambaran yang mengkontruksikan dan menampilkan berbagai fakta dari sebuah objek sehingga dapat memberikan eksplorasi dari sebuah makna yang dapat dilakukan dengan maksimal (Ratna, 2012). Pada umumnya representasi ditemukan dalam sebuah tulisan, percakapan, hingga melalui audio-visual. Hartley (seperti dikutip Wibowo, 2013: p) mengartikan representasi sebagai bentuk penggunaan bahasa untuk mengutarakan suatu hal yang memiliki sebuah makna sehingga dapat merepresentasikan makna tersebut kepada orang lain. Representasi bekerja akibat adanya sebuah hubungan antara tanda dan makna sehingga pemaknaan dari representasi merupakan sebuah proses sosial yang dapat digunakan sebagai suatu sistem penanda dalam sebuah teks, video, maupun film

Dari penjelasan mengenai representasi menurut para ahli di atas, dapat disimpulkan bahwa representasi merupakan sebuah gambaran yang dapat menunjukan maupun mewakilkan sebuah realitas maupun kondisi tertentu, sehingga dapat menghasilkan sebuah makna 
tertentu bagi seseorang yang melihatnya. Dalam penelitian ini, peneliti ingin melihat bagai representasi dari karakter ayah melalui sebuah film yaitu film NKCTHI: Nanti Kita Cerita Tentang Harilni.

\section{Peran Ayah}

Menurut Lamb (seperti dikutip Andayani \& Koentjoro, 2012) keterlibatan seorang ayah dalam sebuah keluarga terdiri dari tiga komponen, yaitu:

a. Parental Engagement yang mencakup kontak dan interaksi seorang ayah dengan anak secara langsung dalam konteks pengasuhan, bermain, hingga rekreasi.

b. Accessibility/Availability yang mencakup aspek kehadiran seorang ayah bagi anaknya, terlepas dari ada atau tidak interaksi antara anak dan ayah.

c. Responsibility yang mencakup kepada pemahaman dari seorang ayah dalam memahami dan memenuhi kebutuhan dari anak seperti faktor ekonomi.

Selain itu, McAdoo (seperti dikutip Parmati \& Purnamasari, 2015) juga mengungkapkan bahwa seorang ayah juga memiliki peran dalam keluarga sebagai berikut:

a. Provider yaitu ayah sebagai penyedia fasilitas, seperti pendidikan dan kebutuhan pokok lainnya.

b. Protector yakni ayah memiliki peran memberi perlindungan dan pengertian mengenai apa yang boleh dan tidak untuk dilakukan anggota keluarganya.

c. Decision Maker yakni ayah juga berperan sebagai pengambill keputusan, sehingga dapat membantu anak untuk mengatasi kesulitan.

d. Child Specialiser \& Educatoryakniayah berperan dalam mendidik dan membimbing anak dalam bersosialisasi.

e. Nurtured Motheryakni serorang ayah juga memiliki peran sebagai pendamping dari seorang ibu, sehingga dapat saling berdiskusi dalam membantu permasalahan keluarga.

Keterlibatan seorang ayah dalam mengasuh anak dalam interaksi yang positif seperti memberikan kehangatanm melakukan kontrol dan pemantauan dalam aktivitas anak, hingga memiliki tanggung jawab dalam kebutuhan anak. Selain itu menurut Hart (seperti dikutip Abdullah, 2010) keterlibatan peran ayah dalam pengasuhan terdiri dari:

a. Economic Provider yaitu ayah sebagai seseorang yang dapat memenuhi kebutuhan finansial anak-anak.

b. Friend and Playmate yaitu ayah sebagai teman untuk anaknya termasuk dalam bermain.

c. Caregiver yaitu ayah sebagai seseorang yang memberikan kasih sayang serta merawat anak-anaknya.

d. Teacher and Role Models yaitu ayah sebagai seseorang yang bisa mendidik dan memberikan contoh dan teladan yang baik bagi anak.

e. Monitor and Disciplinarian yaitu ayah sebagai seseorang yang memantau anakanak dan menegakkan sebuah aturan disiplin.

f. Protector yaitu ayah sebagai seseorang yang dapat menjadi pelindung anak-anak 
dari resiko dan bahaya.

g. Advocate yaitu ayah sebagai seseorang yang mendukung pontensi dari anak untuk kepentingan keberhasilan dari anak.

Dalam keluarga, sosok ayah memiliki peran tertentu yang dapat dilakukan sebagai bentuk dari tanggung jawab maupun kasih sayang. Peran tersebut berbeda dengan bagaimana peran seorang ayah terhadap lingkungan sosial, maupun dalam keluarga besar. Sehingga penelitian ini memiliki fokus terhadap representasi karakter ayah pada keluarga yang terbagi dalam beberapa peran.

\section{Budaya Patriarki}

Istilah patriarki menurut Bhasin (seperti dikutip Adipoetra, 2016; p.3) pada mulanya digunakan untuk menganggap sebuah keluarga yang dikuasai oleh sosok laki-laki. Hingga saat ini istilah patriarki disebut sebagai kekuasaan laki-laki melalui bermacam cara baik dari sebuah sistem tertentu maupun dalam sebuah hubungan kuasa. Sedangkan menurut Munti, patriarki merupakan sebuah sistem otoritas yang menempatkan lakilaki sebagai sosok yang menindas perempuan melalui pranata politik, ekonomi, maupun sosial. (Adipoetra, 2016, p. 3). Langgengnya budaya patriarki dari dahulu kala hingga saat ini di masyarakat Indonesia memunculkan beragam masalah yang membatasi kebebasan maupun hakhak yang dimiliki oleh perempuan (Sakina \& Siti, 2017, p. 72).

Dapat disimpulkan dari penjelasan menurut ahli bahwa partriarki merupakan sebuah kondisi yang menganggap bahwa laki-laki memiliki peran yang berbeda dengan perempuan, dengan menempatkan laki-laki menjadi sosok yang mendapat posisi lebih dibanding dengan perempuan. Hal ini dikaitkan dengan bagaimana karakter dari seorang ayah dalam keluarga yang direpresentasikan melalui film NKTHI: Nanti Kita Cerita Tentang Hari Ini.

Film

Sebuah film dapat merekam fakta dalam kehidupan sehari-hari yang sedang berkembang di masyarakat dan juga dapat menciptakan sebuah kehidupan baru yang berasal dari imajinasi penulis naskah. Film juga akrab bagi segala rentang usia dan beragam kelas sosial sehingga hal tersebut dapat mempengaruhi khalayaknya. Pesan yang terkandung dalam sebuah film dapat memberikan pengaruh, mengubah, hingga membentuk karakter dari penontonnya. Tidak dipungkiri banyak film yang mengangkat kisah nyata yang ada dalam lingkungan masyakarat. Muatan pesan ideologis yang terdapat pada film dapat mempengaruhi pola pikir dari penontonnya (Sobur, 2014).

Melihat film sebagai media komunikasi yang dapat menjangkau banyak khalayak serta dapat menyampaikan sebuah pesan informatif mengenai suatu hal maupun keadaan tertentu maka peneliti ingin melihat bagaimana sebuah film keluarga dengan judul NKCTHI: Nanti Kita Cerita Tentang Hari ini merepresentasikan peran ayah dalam film tersebut.

\section{Karakter}

Karakter juga menjadi sebuah elemen yang penting pada sebuah narasi. Sebuah 
karakter diciptakan agar dapat menjadi pembeda antara satu dan lainnya. Biasanya karakter dibuat berdasarkan emosional, sosial, hingga kualitas mental. Maka dalam sebuah cerita karakter terlibat dalam penggambarkan sebuah peristiwa tertentu (Hallett seperti dikutip Forno, 2015).

Proses karakterisasi merupakan sebuah proses ketika karakter dikategorikan dan dinamakan dengan tujuan dapat menjadi sebuah properti untuk dunia narasi. Hal ini merujuk kepada proses pemberian atribut pada karakter dan dapat dilakukan baik secara tidak langsung berdasarkan dari pengetahuan yang ada lalu disimpulkan menjadi sebuah teks, maupun secara langsung diperlihatkan melalui ciri dari karakter tersebut(Jannidis, 2013).

Dalam penelitian ini penggunaan istilah karakter dipilih berdasarkan tokoh bukan sifat, dikarenakan hal tersebut sesuai dengan istilah untuk film. Sehingga hal ini sesuai dengan tujuan dari penelitian yaitu untuk menjelaskan representasi karakter ayah yang digambarkan melalui film NKCTHI: Nanti Kita Cerita Tentang Hari Ini dan dikaitkan dengan peran ayah dalam keluarga dan juga budaya patriarki.

\section{Analisis Semiotika Peirce}

Menurut Peirce, semiotika merupakan doktrin forman mengenai suatu tanda-tanda. Menurut pandangan Peirce tanda merupakan sesuatu yang hidup dan dihidupi, sebuah tanda dapat mewakilkan sesuatu yang lain. Suatu yang lain dianggap sebagai interpretan (interpretant) dari tanda pertama lalu mengacu pada objek (object) (Budiman, 2011, p. 72). Teori semiotika menurut Peirce sering dianggap sebagai grand theory karena gagasannya memiliki sifat yang menyeluruh dan deskripsi struktural dari semua penanda. Identifikasi dasar dari tanda digabungkan kembali menjadi sebuah komponen dalam struktural yang tunggal (Wibowo, 2013).

Prinsip dasar dari sifat sebuah tanda menurut Peirce merupakan interpretasi dan representatif. Interpretasi menanggap tanda dapat memberikan sebuah peluang interpretasi yang bergantung dengan penerima, sedangkan representatif menganggap tanda adalah sesuatu yang lain. Terdapat tiga wilayah kajian semiotika yaitu(Fiske, 2012):

Semiotika Peirce dikenal dengan model triangle meaning yang hal tersebut terdiri dari:

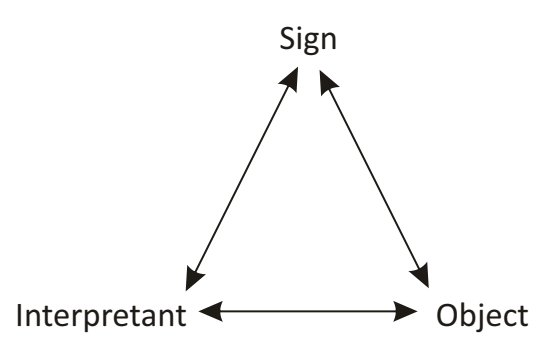

Segitiga Makna Charles Sander Peirce (Tinarbuko, 2008)

1. Sign atau representamen merupakan sebuah bentuk yang dapat diterima oleh indera manusia yang berfungsi sebagai tanda. Sign merujuk kepada hal lain diluar tanda itu sendiri

2. Object adalah sesuatu yang merujuk pada sebuah tanda, sehingga object merupakan sesuatu yang diwakilkan oleh tanda yang berkaitan. Adanya konteks sosial yang menjadi referensi dari sebuah tanda atau sesuatu yang 
dirujuk, sehingga dapat dijadikan sebagai acuan tanda.

3. Interpretant merupakan konsep dari pemikiran seseorang mengenai object yang dirujuk dari sebuah tanda. Pemberian kesan, pendapat maupun pandangan secara teoritis terhadap sesuatu. Hal yang terpenting adalah bagaimana makna muncul dari sebuah tanda yang digunakan seseorang saat melakukan komunikasi.

Dari penjelasan di atas dapat disimpulkan bahwa tanda merupakan sesuatu yang dapat mewakili sebuah hal melalui apa yang didengar, dilihat, maupun dibaca terkait dengan konsep sedangkan objek merupakan apa yang telah diwakilkan oleh tanda sehingga dapat menghasilkan proses interpretan atau penafsiran yang berasal dari konsep yang akan digunakan. Alasan peneliti menggunakan teknik analisis semotika milik Pierce adalah karena teori semiotik ini cocok untuk melihat representasi yang diidentifikasi dan klasifikasi melalui tanda-tanda yang ditampilkan pada film NKCTHI: Nanti Kita Cerita Tentang Hari Ini. Sedangkan jika dibandingkan dengan teknik semiotika lain yaitu teknik semiotika Barthes, peneliti hanya ingin melihat gambaran dari representasi karakter ayah tidak sampai kepada melihat mitos yang ada pada teknik semiotika Barthes. Sehingga dari tanda yang ada pada film tersebut melalui teknik semiotika Pierce dapat menghasilkan sebuah makna yang ada melalui adegan yang ada dalam film.

\section{METODOLOGI PENELITIAN}

Paradigma yang digunakan dalam penelitian ini adalah paradigma konstruktivis, yang memandang bahwa realitas itu adalah hasil konstruksi atau bentukan dari manusia yang bersifat ganda, dapat dibentuk dan merupakan satu keutuhan. Realitas ada sebagai hasil dari pembentukan kemampuan berpikir seseorang. Pengenalan manusia terhadap suatu realitas sosial berpusat pada subjek dan bukan objek, hal tersebut dapat memiliki arti bahwa ilmu pengetahuan bukan hasil dari pengalaman semata, tetapi merupakan hasil konstruksi oleh pemikiran manusia(Arifin, 2012, p. 140).

Penelitian ini menggunakan paradigma konstruktivis karena peneliti bermaksud untuk melihat bagaimana realitas yang dibangun atau dibentuk mengenai karakter ayah melalui film NKCTHI: Nanti Kita Cerita Tentang Hari ini. Sesuai dengan paradigma penelitian yang ditentukan, metode penelitian yang digunakan di dalam penelitian ini adalah metodologi penelitian kualitatif(West \& Turner, 2012).

Metode kualitatif deskriptif menghasilkan dan mengolah data yang dapat memberikan sebuah gambaran melalui sebuah keadaan tertentu, sehingga dapat membuat penelilti memberikan deskripsi mengenai sebuah informasi yang didapat melalui variabel yang digunakan (Soedjono \& Abdurrahman, 2005, p. 19).

Untuk melakukan analisis, peneliti menggunakan semiotika Pierce, melalui tiga proses utama. Pertama melalui sign dengan melihat dari bentuk yang dapat dilihat maupun diterima oleh indera sehingga berfungsi sebagai sebuah tanda yang merujuk pada hal lain diluar tanda itu sendiri. Selanjutnya adalah object. 
Peneliti akan melihat sesuatu yang merujuk pada sebuah tanda tersebut, yang merupakan sesuatu yang berkaitan dengan tanda yang diwakilkan. Selanjutnya menghasilkan interpretant yang menjadi konsep dari pemikiran seseorang mengenai sebuah object yang dirujuk dari tanda, sehingga adanya pemberian kesan maupun pandangan teoritis (Sobur, 2014).

Tahapan tersebut akan dilakukan dalam menganalisis scene yang ada pada film NCKTHI: Nanti Kita Cerita Tentang Hari Ini. Sehingga akan mendapatkan dekripsi dari representasi karakter ayah pada film NCKTHI: Nanti Kita Cerita Tentang Hari Ini. Alasan peneliti menggunakan semiotika untuk melakukan analisis pada sebuah film karena peneliti ingin melihat bagaimana tanda-tanda yang ada pada sebuah film sehingga dapat menghasilkan sebuah representasi tertentu.

\section{HASIL PENELITIAN DAN PEMBAHASAN}

Dari hasil pengamatan terkait penelitian ini menunjukan terdapat adanya penggambaran makna yang berbeda pada setiap scene yang ada dalam film NKCTHI: Nanti Kita Cerita Tentang Hari Ini. Berikut merupakan interpretasi mengenai peran ayah melalui karakter ayah yang ada dalam film NKCTHI :

\section{Care Giver}

Karakter ayah pada film NKCTHI: Nanti Kita Cerita Tentang Hari Ini menggambarkan peran ayah sebagai seorang care giver yakni peran ayah sebagai seseorang yang dapat memberikan kasih sayang serta merawat keluarga. Hal ini ditunjukan melalui scene 1 saat ayah mencoba untuk menenangkan ibu dengan cara memberi ciuman kepada perut ibu yang sedang hamil sebagai bentuk perhatian dan juga kasih sayang. Sehingga karakter ayah dalam film ini menjalankan peran ayah sebagai seorang care giver. Pada scene 20 saat ayah mencairkan dana pensiunnya untuk memenuhi kebutuhan pendidikan Aurora juga menunjukkan kasih sayang seorang ayah dalam bentuk kepeduliannya terhadap anaknya. Selain itu pada scene 21 saat ayah berada di bandara untuk mengantarkan Aurora pergi bersekolah ke luar negeri, sehingga menunjukan bentuk kasih sayang berupa dukungan kepada Aurora dan disertai oleh pelukan yang ayah berikan kepada Aurora sebagai bentuk kasih sayangnya.

\section{Decision Maker}

Karakter ayah pada film NKCTHI: Nanti Kita Cerita Tentang Hari Ini menggambarkan peran ayah sebagai seorang decision maker yakni peran sebagai mengambil keputusan dalam keluarga sehingga dapat membantu mengatasi kesulitan. Hal ini ditunjukan melalui scene 2 saat ayah mengambil keputusan untuk membatalkan makan malam dan kembali kerumah untuk membantu Awan menyelesaikan tugas maketnya, pada scene 7 ayah juga mengambil keputusan untuk memberi perintah kepada Angkasa agar selalu menjemput Awan setiap hari dari kantor. Selanjutnya pada scene 8 ayah juga mengambil keputusan untuk tidak mempertemukan anaknya yang telah meninggal dengan sang istri, scene 19 juga menunjukan ayah yang mengambil keputusan untuk tidak memberi tahu kenyataan 
yang sebenarnya mengenai adik Awan yang sudah meninggal agar dapat menghindari kesedihan anak-anaknya. Melalui beberapa scene yang telah dijelaskan, karakter ayah dalam film ini menjalankan peran ayah sebagai seorang decision maker.

\section{Nurtured Mother}

Karakter ayah pada film NKCTHI: Nanti Kita Cerita Tentang Hari Ini menggambarkan peran ayah sebagai seorang nurtured mother yakni peran seorang ayah sebagai pendamping dari seorang ibu, sehingga dapat saling berdiskusi dalam membantu keluarga. Hal ini ditunjukan melalui scene 3 saat ayah membantu ibu memasak untuk menyiapkan makan malam keluarga, pada scene 19 ayah juga mencoba untuk membantu ibu agar dapat berhatan dari kesedihan demi masa depan keluarga mereka. Melalui beberapa scene yang telah dijelaskan karakter ayah dalam film ini menjalankan peran ayah sebagai seorang nurtured mother.

\section{Child Specialiser and Educator}

Karakter ayah pada film NKCTHI : Nanti Kita Cerita Tentang Hari Ini menggambarkan peran ayah sebagai seorang child specialiser and educator yaitu peran ayah sebagai seseorang yang mendidik dan membimbing anak dalam bersosialisasi. Hal ini ditunjukan melalui scene 4 saat ayah mendidik Aurora untuk saling membantu kepada sang adik, pada scene 8 ayah juga mendidik dan membimbing Angkasa dengan cara menyuruh Angkasa untuk meminta maaf kepada temannya akibat pertengkaran yang telah ia lakukan. Pada scene 9 ayah juga mendidik
Angkasa dengan cara memberi tahu tugas seorang kakak untuk selalu menjaga adik-adiknya. Melalui beberapa scene yang telah dijelaskan karakter ayah dalam film ini menjalankan peran ayah sebagai seorang child specialiser and educator.

\section{Protector}

Karakter ayah pada film NKCTHI: Nanti Kita Cerita Tentang Hari Ini menggambarkan peran ayah sebagai seorang protector yaitu peran ayah untuk memberi perlindungan dan pengertian mengenai apa yang boleh dan tidak untuk dilakukan. Hal ini ditunjukan melalui scene 5 saat ayah memberikan perintah kepada Angkasa untuk tidak melepas adik-adiknya sebagai bentuk perlindungan, pada scene 6 ayah juga memarahi Angkasa karena tidak melaksanakan apa yang telah ia tugaskan yaitu menjempur Awan di kantor. Selain itu pada scene 12 ayah juga mencoba melindungi Aurora dengan cara menghampiri Aurora saat mengalami cedera ketika sedang latihan renang, pada scene 14 ayah juga menjelaskan alasannya untuk memberi perintah kepada Angkasa agar selalu menjemput Awan dikarenakan ia merasa takut akan kehilangan anaknya sebagai bentuk pelindung dari bahaya dan resiko.

Scene 15 juga menunjukan pada saat ayah menjelaskan bahwa ia tidak berniat untuk mengekang melainkan sebagai bentuk peduli dan takut merasa kehilangan. Scene 16 juga menunjukan pada saat ayah berupaya untuk melindungi keluarganya dari kesedihan sehingga dengan cara tidak menjelaskan kenyataan masa lalu yang sebenarnya kepada anak-anaknya. Selain itu pada scene 17 ayah juga menunjukan peran 
sebagai protector dilihat dari bagaimana ia mencoba untuk menutupi kenyataan masa lalu agar seluruh anggota keluarga selalu bahagia dan tidak merasakan trauma kesedihan.

\section{Responsibility}

Karakter ayah pada film NKCTHI: Nanti Kita Cerita Tentang Hari Ini menggambarkan peran ayah sebagai seorang responsibility yakni peran seorang ayah untuk memahami dan memenuhi kebutuhan dari anak. Hal ini ditunjukan pada scene 10 saat ayah mengungkapkan pada Awan bahwa ia telah mempertaruhkan hubungan profesionalnya agar dapat membantu Awan bekerja sesuai dengan tempat yang diinginkan oleh Awan. Sehingga ayah berusaha untuk membantu Awan dengan cara memenuni kebutuhannya.

\section{Monitor and Disciplinarian}

Karakter ayah pada film NKCTHI: Nanti Kita Cerita Tentang Hari Ini menggambarkan peran ayah sebagai seorang monitor and disciplinarian yakni peran ayah sebagai seseorang yang memberi pengawasan serta memantau anakanak untuk dapat menegakkan sebuah aturan disiplin. Hal ini dilihat pada scene 11 saat ayah memarahi Awan karena tidak dapat melaksanakan aturan disiplin yang telah ia buat yang berupa aturan mengenai kehadiran tepat waktu pada saat pameran Aurora. Scene 13 menunjukan pada saat ayah menegur Awan karena tidak bisa menjalankan aturan disiplin karena tidak dapat dihubungi saat tidak bisa hadir tepat waktu saat pameran Aurora, selain itu ayah juga memarahi Angkasa karena menganggap Angkasa membawa pengaruh yang buruk kepada keluarganya.

Pada scene 14 ayah juga menunjukan peran monitor and disciplinarian saat ayah menjelaskan mengapa ia memberikan perintah kepada Angkasa untuk selalu menjemput Awan setiap hari, karena ia merasa takut kehilangan. Scene 16 menunjukan pada saat ayah menegakan aturan untuk tidak memberi tahu kebenaran kepada anak-anaknya agar dapat melindungi dari kesedihan. Scene 17 juga menunjukan pada saat Angkasa mengungkapkan bahwa selama ini ayah telah menutupi kenyataan mengenai masa lalu saat adik dari Awan telah meninggal, dan ayah memilih untuk membuat aturan agar tidak memberi tahu yang sebenarnya kepada Aurora dan Awan.

\section{Advocate}

Karakter ayah pada film NKCTHI: Nanti Kita Cerita Tentang Hari Ini menggambarkan peran ayah sebagai advocate yakni peran ayah sebagai seseorang yang mendukung potensi dari anak untuk kepentingan dan keberhasilan dari anak. Hal ini dilihat pada scene 12 saat ayah menghadiri turnamen renang Aurora sebagai bentuk mendukung potensi yang dimiliki Aurora, dan Aurora mengalami cedera ayah dengan segera menghampiri Aurora untuk memastikan ia terlindungi dari bahaya dan juga resiko. Selain itu pada scene 21 saat ayah dan anggota keluarga lainnya mengantarkan Aurora yang ingin melanjutkan pendidikannya ke luar negeri, dan ayah memberikan support sebagai bentuk 
dukungan kepada keberhasilan Aurora untuk mengejar masa depan yang ia inginkan.

\section{Economic Provider}

Karakter ayah pada film NKCTHI: Nanti Kita Cerita Tentang Hari Ini menggambarkan peran ayah sebagai economic provider yakni peran ayah sebagai seseorang yang dapat memenuhi kebutuhan finansial anak-anak. Hal ini dapat dilihat melalui scene 20 saat ayah mencairkan dana tabungan dari pensiun kerjanya untuk membantu memenuhi kebutuhan anak yaitu Aurora dalam melanjutkan pendidikan di luar negeri.

\section{DISKUSITEORITIK}

Film NKCTHI: Nanti Kita Cerita Tentang Hari Ini merupakan satu dari sedikit film di Indonesia yang menonjolkan karakter ayah yang dibuat pada periode di atas tahun 2000, namun sebenarnya penggambaran karakter ayah dalam sebuah film sudah dilakukan sebelum tahun 2000. Akan tetapi diduga penggambaran karakter ayah pada film-film setelah tahun 2000 mengalami berbagai variasi. Terkait dengan karakter ayah dalam sebuah film keluarga, sosok ayah pada film yang ada pada tahun sebelum 2000 sangat lekat dengan budaya patriarki. Karakter ayah digambarkan sebagai seorang laki-laki yang maskulin dan memiliki kuasa dalam keluarga yang ditampilkan melalui karakter ayah. Seperti pada film Warkop DKI, Di Balik Kelambu dan lain sebagainya yang menggambarkan sosok ayah sebagai seseorang yang mencari nafkah atau sebagai financial support, selain itu karakter ayah juga ditampilkan sebagai sosok yang dominan terutama pada anak perempuannya.

Hal ini mengalami pergeseran yang ditunjukkan dengan adanya perbedaan pada film di atas tahun 2000 yang menampilkan karakter ayah dalam keluarga. Karakter ayah diperankan sebagai sosok yang lebih humanis dapat dilihat dari bagaimana sosok ayah mulai mengalami peralihan dalam hal melakukan pekerjaan domestik yang sebelumnya menjadi kegiatan ibu. Hal ini tampak melalui salah satu adegan pada film NKCTHI: Nanti Kita Cerita Tentang Hari ini saat seorang ayah membantu ibu memasak untuk mempersiapkan makan malam keluarga. Pada film Indonesia lainnya di seperti Keluarga Cemara, sosok ayah juga ditampilkan sebagai sosok yang melakukan pekerjaan domestik yaitu pada adegan saat ayah membantu mengasuh anak laki-lakinya saat sedang berlatih tarian drama.

Sosok Ayah merupakan sandingan dari sosok ibu, sehingga ketika ayah disandingkan dengan ibu terdapat pembagian peran. Laki-laki dan perempuan dibedakan berdasarkan gender. Pembagian peran tersebut membentuk sebuah konstruksi yang terkait dengan suatu budaya, lakilaki memiliki peran publik sedangkan perempuan memiliki peran domestik dalam keluarga. Pembagian peran tersebut terbawa untuk ditampilkan kedalam karakter ayah yang ada pada film di Indonesia setelah tahun 2000. Hal yang menarik pada film NKCTHI: Nanti Kita Cerita Tentang Hari Ini adalah karena film ini merupakan salah satu film yang menggambarkan karakter ayah dengan peran yang lebih humanis dan lebih menunjukan kasih sayang baik berupa peduli hingga dukungan terhadap anak seperti pada 
scene saat ayah memberikan dukungan kepada Aurora untuk melanjutkan pendidikan ke luar negeri. Namun dalam film ini ayah tetap dianggap sebagai sosok yang memenuhi peran financial support, hal ini dapat dilihat dari film-film yang ada sebelum tahun 2000 hingga film-film di atas tahun 2000.

Keluarga merupakan sebuah sistem yang di dalamnya terdapat unsur maupun komponen yang memiliki kaitan dengan interaksi antara satu dan yang lain, serta dalam keluarga juga terdapat aturan tertentu yang berlaku. Ayah menjalakan perannya yang merupakan bagian dari sebuah sistem yang ada dalam keluarga. Dalam sistem tersebut setiap anggota keluarga memikili peran maupun posisi tertentu sesuai dengan fungsinya, antara peran orang tua dan anak maupun peran suami dan istri. Dalam sistem tersebut terbangun sebuah hubungan yang saling bergantung dan terhubung satu sama lain.

Ketika seorang ayah dalam keluarga membuat sebuah aturan seperti pada adegan di film NKCTHI: Nanti Kita Cerita Tentang Hari Ini seperti saat ayah meminta Angkasa sebagai kakak tertua untuk selalu menjemput Awan sebagai adik terakhir sepulang bekerja di kantor, hal tersebut merupakan sebuah sistem yang dijalankan oleh ayah sesuai dengan peran nya sebagai kepala keluarga. Aturan-aturan tersebut akan dipertahankan dalam kehidupan sehari-hari dalam keluarga. Jika dikaitkan dengan budaya patriarki, karakter ayah pada film ini masih memiliki peran yang dominan terutama pada saat menegakan aturan dan pengambilan keputusan.

Ayah sebagai sosok laki-laki yang menjadi kepala keluarga cenderung memberi pengertian mengenai apa yang boleh atau tidak untuk dilakukan oleh anggota keluarganya. Karakter ayah pada film ini dianggap memiliki kekuatan lebih dalam ranah privat atau rumah tangga yang berpengaruh dalam sebuah kebijakan maupun pengambilan keputusan sesuai dengan bagaimana tanggapan mengenai budaya patriarki yang menjadi sebuah sistem. Akan tetapi, meskipun budaya patriarki masih melekat dalam film NKCTHI: Nanti Kita Cerita Tentang Hari Ini, tidak dipungkiri adanya sebuah kebaruan yang membedakan film yang ada di atas tahun 2000 ini. Ada variasi mengenai peran ayah sebagai kepala keluarga yang mulai beralih untuk menjalankan peran domestik dan menunjukan kasih sayang serta kepedulian terhadap keluarga. Dengan demikian, film NKCTHI: Nanti Kita Cerita Tentang Hari Ini memberikan kebaruan mengenai representasi karakter ayah dibandingkan flm-film sebelumnya.

\section{KESIMPULAN}

Berdasarkan hasil penelitian dan pembahasan yang telah dijabarkan pada bab sebelumnya, penelitian ini memiliki fokus utama pada representasi karakter ayah pada film NKCTHI: Nanti Kita Cerita Tentang Hari Ini. Terdapat 21 scene yang menggambarkan representasi dari karakter ayah yang ada pada film ini. Karakter ayah di representasikan dalam bentuk berbagai peran yang ada di dalam keluarga.

Karakter ayah direpresentasikan dalam 
peran ayah sebagai seorang care giver. Peran tersebut merupakan peran ayah sebagai seseorang yang dapat memberikan kasih sayang serta merawat keluarganya ditunjukan melalui bagaimana ayah memperlihatkan kepeduliannya kepada anggota keluarganya, hal ini merupakan sebuah kebaruan karena bentuk peduli dan kasih sayang pada film keluarga sebelum tahun 2000 cenderung lebih terlihat dari sosok ibu. Karakter ayah juga direpresentasikan dalam peran ayah sebagai seorang decision maker. Selain itu karakter ayah juga direpresentasikan dalam peran ayah sebagai seorang nurtured mother. Peran ayah sebagai seorang child specialiser and educator juga direpresentasikan melalui karakter ayah dalam film ini. Karakter ayah juga direpresentasikan dalam peran ayah sebagai seorang protector saat memberikan perlindungan serta pengertian mengenai apa yang boleh dan tidak untuk dilakukan oleh anggota keluarganya. Peran ayah sebagai responsibility juga direpresentasikan dalam film ini.

Karakter ayah juga direpresentasikan dalam peran ayah sebagai seorang monitor and disciplinarian dan peran ayah sebagai seorang advocate. Terakhir, peran ayah sebagai economic provider yang dapat memenuhi kebutuhan finansial anak-anaknya dan bertanggung jawab terkait kebutuhan finansial untuk pendidikan anaknya juga direpresentasikan.

Dari keseluruhan peran ayah yang direpresentasikan melalui film ini, karakter ayah cenderung memiliki peran sebagai seorang protector yakni seorang yang selalu mencoba untuk memberikan perlindungan dan pengertian mengenai apa yang boleh dan tidak melalui aturan-aturan yang telah ia tentukan. Jika dikaitkan dengan budaya patriarki yang menenmpatkan laki-laki sebagai sosok yang lebih dominan dalam keluarga, karakter ayah pada film ini menjadi sosok yang dominan yang diperlihatkan melalui proteksi kepada anggota keluarganya. Peran proteksi tersebut dilakukan sebagai bentuk peduli terhadap keselamatan keluarga, tetapi anggota keluarga khususnya anakanak memaknai hal tersebut berbeda mereka menganggap hal tersebut adalah sebuah tekanan yang membatasi mereka.

Menariknya, secara psikologis sikap protektif merupakan salah satu faktor yang mempengaruhi resiliensi seseorang yang merupakan sebuah kemampuan untuk beradaptasi dalam mengatasi suatu masalah atau trauma (Wright, Masten, \& Narayan, 2013),

Selain itu temuan penelitian dari film ini jika dikaitkan dengan kesetaraan gender yang menempatkan perempuan dan laki-laki memiliki kesempatan yang sama dan setara dalam berperan untuk memenuhi hak serta kewajibannya (Djoharwinarlien, 2012), karakter ayah yang masih menjadi sosok dominan menunjukan bahwa belum adanya bentuk kesetaraan gender pada film ini. Hal ini dapat dilihat dari bagaimana sosok perempuan atau ibu pada film ini belum memiliki kesempatan yang sama dalam hal pengambilan keputusan.

Temuan penelitian ini berhasil menjelaskan representasi karakter ayah. Penelitian berikutnya diharapkan melakukan analisis resepsi peran ayah di film NKCTHI di kalangan para ayah. Bila dalam penelitian ini menggunakan semiotik Pierce, kedepannya bisa 
menggunakan semiotik Barthes untuk mencari mitos terkait peran ayah dalam keluarga menurut budaya patriarki.

Selain itu hasil dari penelitian ini diharapkan dapat digunakan sebagai wacana di kalangan kreator film terkait pengemasan peran karakter ayah dalam keluarga. Sementara bagi masyarakat, dapat berguna sebagai wacana bahwa saat ini ayah juga menjalankan peran di sektor domestik.

\section{DAFTAR PUSTAKA}

Abdullah, S. M. (2010). Keterlibatan Ayah dalam Pengasuhan Anak (Parental Involvement) :Sebuah Tinjauan Teoritis. Yogyakarta.

Adipoetra, F. G. (2016). Representasi Patriarki dalam Film "Batas". 3. Surabaya

Agmassini, G. (2019,Juli 31). Pentingnya Peran Ayah pada Kepribadian Si Kecil. Retrieved from Line Today: https://today.line.me/id/v2/article/Penti ngnya+Peran+Ayah+pada+Kepribadian+S $\mathrm{i}+$ Kecil-kXB3L1

Andayani, B., \& Koentjoro. (2012). Psikologi Keluarga: Peran Ayah Menuju Coparenting. Sidoarjo: Laros.

Arifin, Z. (2012). Penelitian Pendidikan Metode dan Paradigma Baru. Bandung: PT. Remaja Rosdakarya.

Budiman, K. (2011). Konsep Isu dan Problem Ikonisitas. Yogyakarta: Jalasutra.

Dewi, B. K. (2017, November 10). Peran Ayah dalam Tumbuh Kembang Anak 10 Nov 2017 00:00:00. Retrieved from Sahabat Keluarga, Kementrian Pendidikan dan Kebudayaan: https://sahabatkeluarga. kemdikbud.go.id/laman/index.php?r=tp ost $/$ xview\&id=4457

Diananto, W. (2020, Januari 22). Film NKCTHI Akhirnya Tembus 2 Juta Penonton. Retrieved from Liputan 6: https://www. liputan6.com/showbiz/read/4161229/fil m-nkcthi-akhirnya-tembus-2-jutapenonton

Djoharwinarlien, S. (2012). Dilema Kesetaraan Gender. Yogyakarta: Research Center for Politics and Government (PolGov).

Eliyanah, E. (2018). Dari Rangga ke Khudori, 'lakilaki baru' di film Indonesia. Retrieved from The Conversation: https:// theconversation.com/dari-rangga-kekhudori-laki-laki-baru-di-film-indonesia82759

Fiske, J. (2012). Pengantar IImu Komunikasi. Jakarta: PT. Rajagrafindo Persada.

Forno, D. M. (2015). Penggambaran Karakter pada Tokoh Utama dalam Film Maleficent. Surabaya.

Hidayat, L. (2019, Ferbruary 24). Sederhana Tapi Penting, Inilah Manfaat Menonton Film Keluarga. Retrieved from Futuready: https://www.futuready.com/artikel/famil $\mathrm{y} /$ sederhana-tapi-penting-inilahmanfaat-menonton-film-keluarga/

Ibrahim, I. S. (2011). Budaya Populer Sebagai Komunikasi, Dinamika Popscape dan Mediascape di Indonesia Kontemporer. Yogyakarta: Jalasutra.

Jannidis, F. (2013). The Living Handbook of Narratology. Hamburg: Hamburg University Press.

Javandalasta. (2011). 5 Hari Mahir Membuat Film. Jakarta: Gramedia. 
Lestari, S. (2012). Psikologi Keluarga Penanaman Nilai dan Penanganan Konflik dalam Keluarga. Jakarta: Kencana Prenada Media Group.

Luviana. (2020, Januari 20). Film NKCTHI: Ini Cerita tentang Keluarga yang Normatif dan Patriarki. Retrieved from Konde.co: https://www.konde.co/2020/01/filmnkcthi-ini-cerita-tentang-keluarga.html

Noor, D. A. (2020, Juli 24). Bangga, Film NKCTHI Akan Tayang 2 Kali di Shanghai International Film Festival. Retrieved from Askara.co: https://www.askara.co /read/2020/07/24/7003/bangga-filmnkcthi-akan-tayang-2-kali-di-shanghaiinternational-film-festival-

Parmati, \& Punamasari, S. (2015). Peran Ayah Dalam Pengasuhan Anak. Yogyakarta.

Widiyasa, P. P. (2017). Representasi Maskulinitas pada Sosok Ayah di Majalah Keluarga Ayahbunda.

Rahman, I. M. (2020, Juli 15). Wow! Inilah 5 Fakta Mencengangkan Budaya Patriarki di Indonesia! Retrieved from HerStory: https://herstory.co.id/read5039/wowinilah-5-fakta-mencengangkan-budayapatriarki-di-indonesia

Ratna, N. K. (2012). Penelitian Sastra: Teori, Metode dan Teknik. Yogyakarta: Pustaka Pelajar.

Revitasari, F. (2019, April 29). 5 Alasan Kenapa Budaya Patriarki Masih Ada di Indonesia. Retrieved from IDN Times: https://www. idntimes.com/life/women/vita/alasanbudaya-patriarki-masih-ada-diindonesia/5

Rizqullah, R. '. (2019, Maret 02). Perempuan dalam Dominasi Patriark. Retrieved from Medium.com: https://medium. com/lingkaran-solidaritas/perempuandalam-dominasi-patriarki-b7659347e9d7 Rokhmansyah, A. (2013). Pengantar Gender dan Feminisme. Yogyakarta: Garudhawaca.

Romli, K. (2016). Komunikasi Massa. Jakarta: PT. Grasindo.

Sakina, A., \& Siti, D. H. (2017) Menyoroti Budaya Patriarki di Indonesia. 72. Bandung.

Skata. (2020, Januari 6). Ayah, Biarkan Anakmu Merasakan Gagal dan Kecewa (Review Film NKCTHI). Retrieved from Kumparan: https://kumparan.com/skata/ayahbiarkan-anakmu-merasakan-gagaldankecewa-review-film-nkcthi1saalqDVy3s/full

Sobur, A. (2014). Semiotika Komunikasi. Bandung: PT. Remaja Rosdakarya.

Soedjono, \& Abdurrahman. (2005). Metode Penelitian Suatu Pemikiran dan Penerapan. Jakarta: Rineka Cipta.

Sukarno, E. (2019, Oktober 9). Perempuan dalam Cengkraman Budaya Patriarki. Retrieved from Radarjogja: https://radarjogja .jawapos.com/2019/10/09/perempuandalam-cengkraman-budaya-patriarki/

Suyanto, B. (2020, Februari 29). Bias Patriarki dalam RUU Ketahanan Keluarga. Retrieved from Media Indonesia: https://mediaindonesia.com/read/detail /293282-bias-patriarki-dalam-ruuketahanan-keluarga

Tan, P. (2014, Januari 10). Mendobrak Patriarki dalam Rumah Tangga. Retrieved from Kompasiana: https: / / w w w . 
kompasiana.com/poedjiatitan/5528ba30 f17e610a7c8b4694/mendobrakpatriarki-dalam-rumah-tangga

Tinarbuko, S. (2008). Semiotika Komunikasi Visual West, R., \& Turner, L. H. (2012). Pengantar Teori Komunikasi Analisis dan Aplikasi. Jakarta: Salemba Humanika.

Wibowo, I. S. (2013). Semiotika Komunikasi. Aplikasi Praktis Bagi Penelitia dan Skripsi Komunikasi. Jakarta: Mitra Wacana Media.

Wright, M. O., Masten, A. S., \& Narayan, A. J. (2013). Resilience Processes in Development: Four Waves of Research on Positive Adaptation in the Context of Adversit. 15-37. New York: Springers US. 